\title{
Theme of Wandering Identity in VS Naipaul's Half a Life
}

\author{
Dr. Lekha Nath Dhakal
}

Associate Professor, Tribhuvan University, Nepal Commerce Campus, Kathmandu, Nepal

\begin{abstract}
VS Naipaul's protagonist, Mr. Willie in Half a Life, undergoes the pain of having wandering identity and being displaced from his native land. He wanders for cultural root in an unfamiliar environment. Naipaul, through his great sensibility, has manifested his own pursuit for 'home' and 'root' through his protagonist. The protagonist symbolizes the agony of rootless and displaced people who are destined to lead a wandering life on this earth. Unquestionably, the loss of identity and a search for root happens to be the features of Naipaul's works. However, Willie finds his own way to make his life meaningful through hybrid identity. Finally, Willie strives and aspires to recreate a new sense of cultural root through a profound reception and working through his own position as a permanent exile and rootless subject.
\end{abstract}

Keywords-Wandering Identity, Hybridity, Dislocation, Alienation.

This article makes an attempt to analyze the novel, Half a Life by VS Naipaul from the perspective of wandering identity and hybridity, which are the recurrently used vocabularies in post-colonial studies. The features of diasporic literature are also discussed here. The major theme of diasporic literature is dislocated identity of an individual. The sense of rootlessness drives an individual to sense of dislocation which is the bottom line of VS Naipaul's novel Half a Life. Through the mentioned autobiographically-driven novel, VS Naipaul has exposed his own reflections.

Wandering identity is a state suffered by the uprooted, the marginal and the exiled. The displacement and dispossession that immigrants are subjected to, bring them into a limbotic position, the agony of which aggravates when all efforts of assimilation are disillusioned. Caught up in limbo, the immigrants lose not only their native place but also their identity. All their efforts at assimilation then are directed towards their search for a face, attrition of heritage language striving towards acculturation. Quest for identity is going to be a major recurring theme in literature the world over, for some years to come. Quest for identity has a broad spectrum meaning and it has been manifested in various ways in the will to exist despite all odds and to survive all odds. This takes many names and it is very important in fact, one of the most important factors in the life of an individual as well as that of a nation and a race.
A number of cultural theorists have expounded on the fluid and unstable status of "culture." Stuart Hall speaks of unfixed identity; James Clifford's traveling theory, Doreen Massey of identity and place, HomiBhabha of mimicry, hybridity, and "third space." All of these ideas have been applied to explain V. S. Naipaul's position of (both voluntary and involuntary) exile. Stuart Hall claims that identity makings are "never singular but multiple, constructed across different, often intersecting and antagonistic, discourses, practices and positions" ("Who Needs Identity?" 4).

Travel also has a significant effect on one's concept of place and home. James Clifford speaks of the need to rethink cultures as sites for dwelling and traveling. He sometimes equates "travel" with "displacement." Travelers are comfortable with more than one culture, so the question is not "Where are you from?" but "Where are you between?" ("Traveling Cultures" 109). Travelers are affected by the sites they travel to; traveling and dwelling conjointly affect (and help to determine) one's identity. Even if he had a largely mono-ethnic, mono-cultural background, Naipaul would be regarded as a "citizen of the world" as a result of his excessive and constant traveling. Thus, even in the more "normal" case culture and identity may be relatively moveable, changeable, unfixed entities. However, someone like Naipaul, with a complex and diverse ethnic and colonial background, needs a special kind of strength and resilience, a special ability to contain and manage his/her multiplicity of cultural identities. In 
addition, such people are especially likely to be not just travelers and tourists but immigrants and even refugees.

Naipaul also describes, in some works, the particular suffering and identity-confusion of immigrants. Aiming to assert "himself," to claim his identity and find his place in the world, then, Naipaul must articulate his multiple identities; eventually he is satisfied with the state of exile, of belonging nowhere and yet everywhere, although he undergoes a long period of solitude in his life. forms of state mechanisms.

In our "post-colonial" world, the concept of identity is linked to a local sense of place, and identity-creation shifts on account of the effect of colonialism and globalization. In terms of Doreen Massey's concept of identity and place, connecting the traditional sense of place to one's original roots can offer a stable identity. Nevertheless, "the concept of place is not static but unstable" and "places are processes" (Massey 155). Massey says of the reproduction of place:

Places do not have single, unique "identities"; they are full of internal conflicts [...] [such as] conflict over what its past has been (the nature of its "heritage"), conflict over what should be its present development, conflict over what could be its future. None of this denies place nor the importance of the uniqueness of place. The specificity of place is continually reproduced. (155)

In an interview with Bernard Levin in 1983, Naipaul metaphorically explained his concept of multi-cultural identities: "I don't think any of us can claim that we come from one single, enclosed, tribal world. We are little, bombarded cells, aren't we? - many things occur to make us what we are, and we can surely live with all the things that make us" (98). Massey's theory lends support to the observation that Naipaul, as a nomad, can live in different places, though he may not feel himself to be ever intrinsically "at home."

In addition, HomiBhabha's concept of mimicry, hybridity, and the third space best sums up Naipaul's colonial situation (or predicament), his ambivalence, his search for identity and the narrative strategy that emerges from it. At first "mimicry" was the method by which the British imperial power controlled and dominated the colonized people in the nineteenth century: the British rulers made the colonials "imitate" the culture and language of the colonizer (the British Empire); thus the ideology of the colonized was drastically changed, and became-as an inevitably "poor imitation" of the "original" - inferior to that of the colonizer. However, in the post-colonial era writers began to use mimicry as a counter strategy, "writing back" to the imperial power and negotiating their own position or place with respect to the mother country. In "imitating" the English language and even the form of the English novel, writers like Salmon Rushdie (and to a lesser degree also Naipaul) can of course also mock and parody various aspects of the "imperial" tongue and culture; they've learned so well from their "masters" that they now know how to make fun of what they have been taught, show its intrinsic weaknesses and absurdities. The process of mimicry thus creates a new entity through the difference between self and other.

The attitude of a colonial also determines whether the inevitable stage of mimicry can create obstacles or greater force in one's search for self-identity. Consequently, Naipaul's hybrid identities can never be wholly constructed "from the origin" because he needs to renew his powers of articulation. Although Naipaul was educated in the mother country, England, it still remained his second home. Even Trinidad was an alien land for him because he always felt slightly like a stranger. He could not authentically feel truly at home in any one place; therefore, all of his "homes" form his hybrid identities. He himself must creatively articulate his distinguishing cultural "features." To HomiBhabha, such hybridity is "the most common and effective form of subversive opposition" (Ashcroft 9); Robert Young says that Bhabha's concept of hybridity has transformed Bakhtin's intentional hybridity into "an active moment of challenge and resistance against a dominant cultural power" (23). The hybridity of colonial discourse reverses the dominant structures in the colonial situation. Thus, it deploys dialogue between the dominant and the subordinate, forming (in Bakhtin's terms) a "double-voiced talk."

Bhabha further employs the concept of "the third space" to explicate the concept and the goal of hybridity. Speaking from a colonial standpoint, he elaborates on "the third space" as a strategy for opening up the possible space of cultural discourse by transcending cultural hegemony and crossing over its historical boundaries. Bhabha sees the key problems of cultural diversity as tied to the initial "norm given by the host society or dominant culture," and to multiculturalism based on racism (Identity 208). Therefore he tries to look for the "productive space of the construction of culture as difference, in spite of alterity or otherness," to show that different cultures have their own unique characteristics and that they are incommensurable (Identity 209). Bhabha introduces the notion of "cultural translation" as a way of negotiation between two cultures. This translation is a way of imitating an original which can be "simulated, copied, transferred, transformed, made into 
a simulacrum" (Identity 210). Translation is the passage between the original and the simulacrum. Thus the original is always being created again and again, just like the simulacrum itself. Cultural translation "opens up the possibility of articulating different, even incommensurable cultural practices and priorities" (Identity 210-11). The socalled "third space" is thus produced in the process of translation, and negotiation can become a form of aggressive subversion and aggression through which a new site is established.

Wandering identity can then be produced as a new site through the process of hybridization. Bhabha insists that a "cultural and political identity is constructed through a process of othering" because the history of containment is now overcome and minority discourse emerges (Identity 219). Hence, the dialogue between cultures "beyond Orientalism" (Said) erases the misrepresentation or mere imagination of a given culture. Bhabha also speaks of the responsibility of intellectuals. He thinks that intellectuals (like Naipaul) should "intervene in particular struggles, in particular situations of political negotiation" (219). In other words, they are in a position of opposition from which to examine cultural politics: thus Naipaul, as an intellectual with his own cultural particularity and position, can and should speak for the marginalized. Bhabha also claims that the colonial is neither "the colonialist Self nor the colonized Other but the disturbing distance in-between that constitutes the figure of colonial otherness" (The Location of Culture 45). Bhabha's theory of in-between borderlines challenges the traditional concept of "place." Naipaul then turns his sense of alienation into a powerful capacity to feel at home in any place.

The cultural critic Andrew Gurr argues that a definition of home can be derived from the relationship between the exile and his writing in the modern world; that is, the displaced exile may obtain his/her identity primarily through his/her writing. As BreytenBreytenbach points out, "To be in exile is to be free to imagine or to dream a past and the future of that past. To be an exile is to be written" (69). Naipaul, as an exiled writer, can create his own place through traveling and writing. This "in-between" space provides him with a broader imaginative and creative space. The space of the "in-between" also gives the exile, the immigrant, the migrant, the colonial to have more chance to choose possibilities from their multi-cultural background. It goes without saying that their identity will not be fixed, won't be defined by the past. The exile of the twenty-first century inevitably negotiates between spaces as between cultures; he negotiates and makes or finds a temporary "place" for himself between cultural spaces. And writing is a very potent way of performing such a negotiation. Also, writing, as reflected in Half a Life, for Willie, offers a way to create and construct his racial subjectivity; meanwhile, provides him with the opportunity to re (in) trospect his past history.

The novel is set in three locales - India, England and Africa. A princely State in British Indian untouched by colonial agitation is the setting of the first part of the novel entitled "A visit from Somerset Maugham". The second part entitled 'The first chapter' is set in post - war London with its dingy West End clubs and lonely pavements and the third part called 'A second Translation' has setting in a province of Portuguese Africa. The Protagonist Willie Chandran, born in India of a Brahmin father and a lower class mother, leaves India and goes first to England and then to Africa. Willie's life in London is fraught with many frightening experiences. He is portrayed as a young man with nothing to his name but his promise as a writer, drifting aimlessly, groping for a voice. He suffers from displacement and emptiness - a sense of being without history or understanding, the difficulty a writer from the colonies faces in finding material and his shocking sexual encounters. He sleeps with prostitutes and friend's girlfriend only to discover his own sexual incompetence.

Willie Chandron, the protagonist of V.S. Naipaul's Half a Life, is a bitter young Indian, and it doesn't help when his father clarifies a few shameful details of his family's past. "I despise you," Willie tells him, and really he despises everything his passionless life has presented him. He goes to London and then Africa to reinvent himself.

Willie arrives in London not knowing anything. He drifts from bars to dinner parties to newspaper offices, and our fun lies in watching him observe odd social customs and sad class incongruities. Pretentious Brits admit him to their circles, as a mirror or an oddity, and every few pages they say something condescending about India. Naipaul presents London terrifically, as a town of impressionable young heirs still learning to promote themselves in a world shaped by imperial forbears. Everyone looks up to their ancestors for having created such splendor.

Then Willie falls in love, gets married and moves to Portuguese, East Africa. He spends 18 years there, an outsider again, but this time on the side of the crumbling empire, as his middle-class wife, Ana, is mainly Portuguese. His house is concrete, not mud, and he weekends with Ana's European. Willie is still a little displaced in Africa, but not much more so than, say, a Richard Ford character casting about in New Jersey. His trusty alienation now somewhat toothless, Willie submits 
to the consolations of bourgeois comfort. Granted, this is the bush version of bourgeois, and it includes sex with young African girls, but the point is he's no longer rudderless in London.

Through the character, Willie and his constant and continuous journey from one place to another so as to search his identity and selfhood, V S Naipaul is trying to express and expose the plight and predicament of the exiled and dislocated in postcolonial social set up. Naipaul decided to take up writing as his vocation he had to look for an authentic voice, so he preferred to draw on his personal experience of an uprootness adrift in the two worlds to neither of them he could belong. Rootlessness and displacement are the predominant themes of the hereby mentioned novel.

Willie thus possesses only "half a name." The novel seems to reveal Willie's father's intention that his sons "mimic" the whites, since he gave him half of a white man's name. Willie can clearly see the gap between the colonial's mimicry of the colonizer and his desire to construct himself in a chaotic world. He is aware of the paradoxical nature of his mimicry. However, he becomes a "mimic man," the person people expect him to be, just like Ralph Singh in The Mimic Men. As a matter of fact, the Western name is hollow because he cannot possess a Western identity simply by possessing a western name. In contrast, identifying with the Western name and dismantling his Indian name symbolizes the loss of his original culture. He is still excluded in and from "Western space" though his father intends to "bleach" him through giving him a halfwhitened name.

Worst of all, Willie cannot face his real ancestral history, his true genealogy. He employs his imagination to shape a make-believe identity and tries to live behind its mask. This is implied in the given statement. As the narrative goes further:

$[\mathrm{H}] \mathrm{e}$ adapted certain things he had read, and he spoke of his mother as belonging to an ancient Christian community of the subcontinent, a community almost as old as Christianity itself. He kept his father as a Brahmin. He made his father's father a 'courtier.' So playing with words, he began to re-make himself. It excited him and began to give him a feeling of power. (61)

In the above mentioned quotation we can see that how fabricated stories can give one a kind of solace in a foreign land, which is dislocated from one's own.

In London, at least, he was a writer known as Willie Chandran, but in Africa he becomes merely "Ana's ISSN: 2456-7620
London man" (145). He is unable to find a place for himself in Africa; worse, he loses his autonomy. He goes nowhere. He becomes nothing. His only consolation is that he ironically discovers an affinity with "half-and-half friends" (162) in this "half-and-half world" (160). These friends regard themselves as "the second rank" (160) including Correias, Ricardo and Luis (the estate manager of Carla Correia) and his wife Grace. Willie portrays Correias's plight thus:

To destroy a Portuguese like himself would have been to break caste, according to the code of the colony, and to become disreputable. There was no trouble at all in throwing a man of the second rank into darkness, someone from the half-and-half world, educated and respectable and striving, unusually knowledgeable about money, and ready for many reasons to do whatever he might be required to do. (174)

It is clear in the hereby mentioned statement that the dislocated people share Willie's sense of loss, disorientation, and dereliction. Willie sees his own shadow in his half-and-half friends. Through their images of reflection, he gets epiphany to understand that, by employing the perspective of the "other," he becomes even more trapped.

After staying in Africa for one year, Willie witnesses his "half-and-half friends" who intend to bleach their identities:

But then after a year or so I began to understand - and I was helped in this understanding by my own background - that the world I had entered was only a half-andhalf world, that many of the people who were our friends considered themselves, deep down, people of the second rank. They were not fully Portuguese, and that was where their own ambition lay. (160-61)

Through his objective observation, he consciously understands that he shares the homogenous cultural heritage and loss with them. Originally, he intended to bleach his family history and cultural roots; however, Willie discovers his loss of his precious cultural background when he looks back on his journey from India, England and then to Africa. Thus, he finds his cultural heritage and desires to construct his subjectivity. Finally, he decides to end his wandering time and escape days.

The loss of identity, sense of alienation and exile is the lot of the mixed, unpedigreed class. The stigma of being a second rate citizen hangs around Willie all the 
time. Willie gets temporary relief due to some slippery substance which awakes him to the futility of all his efforts in a half-made society. In Africa Willie gradually finds some solace in the realization that he is not the only one bearing the burden of being dislocated; there are many like him who are infested with a sense of double exile. He discovers he is in "a half-and-half world (160) with "halfand-half friends" (162) who had come to reconcile with their position as "people of the second rank" (160). In Berlin describing the plight of Correias to Sarojini Willie says:

To destroy a Portuguese like himself would have been to break caste, according to the code of the colony, and to become disreputable. There was no trouble at all in throwing a man of the second rank into darkness, someone from the half-and-half world, educated and respectable and striving, unusually knowledgeable about money, and ready for many reasons to do whatever he might be required to do. (74)

Here, the protagonist is feeling dislocated position having second ranked citizen in the foreign land. Despite all adverse circumstances Willie still feels much at home among the Africans.

Willie comes to see this plain truth in time and decides to call it a day. For years he has allowed himself to become easy victim to slippery substances but on a rainy day when he slips after having spent eighteen years in Africa, he comes to realize that at forty-one, it's high time to stop making a fool of him. He wants to emerge out of the shadow of the image of 'Ana's London man', which was thrust on him without his knowing. He is resolved that there are not going to be any more slips for him. Resolutely he tells Ana: "I mean I've given you eighteen years. I can't give you any more. I can't live your life any more. I want to live my own" (136). Ana is in the same boat and she knows the agony too well. She has herself been leading a borrowed life. She tells Willie: "Perhaps, it wasn't really my life either" (128).

\section{Conclusion}

Summing up, Willie, in Half a Life just like VS Naipaul himself, has the dislocated identity. It is through multicultural and fluid identity; Willie attempts to find meaning in the places of multicultural hullabaloo. By assimilating the dynamic identity in multicultural social set ups, he makes an attempt to establish meaning in his rootless identity. Within distinctly dynamic identity of being rootless, Willie persistently motivates himself to enjoy life at its fullest.

\section{REFERENCES}

[1] Chare, Nichiolas. "The Gap in Ashcroft, Bill, Gareth Griffiths, and Helen Tiffin. The Empire Writes Back:

a. Theory and Practice in Post-colonial Literatures. Routledge, 1989.

[2] Bakhtin, Mikhail. Problems of Dostoevsky's Poetics. Ed. and Trans. Caryl Emerson. Manchester UP, 1984.

[3] Bhabha, Homi. "Of Mimicry and Man: The Ambivalence of Colonial Discourse." The Location of Culture. Routledge, 1994, pp. 85-92.

[4] ---. "The Third Space." Identity: Community, Culture, Difference. Ed. Jonathan Rutherford. Lawrence \&Wishart, 1990, pp. 207-21.

[5] ---. "Culture's In-Between." Questions of Cultural Identity. Ed. Stuart Hall and Paul Du Gay. SAGE Publication, 1996, pp. 53-60.

[6] ---. "The World and the Home." Social Text vol. 31, no, 32 pp. 141-153.

[7] Breytenbach, Breyten. "The Long March from Hearth to Heart." Home: A Place in the World. Ed. Arien Mack. New York UP, 1993. 65-80.

[8] Clifford, James. "Traveling Cultures," Cultural Studies. Routledge, 1992.

[9] Gurr, Andrew. Writers in Exile: The Identity of Home in Modern Literature. The Harvester Press, 1981.

[10] Hall, Stuart. "Cultural Identity and Diaspora." Colonial Discourse and Post-colonial Theory. Ed. Patrick Williams and Laura Chrisman. Cambridge UP, 1993. pp.392-403.

[11] ---. "Who Needs 'Identity'?" Questions of Cultural Identity. Ed. Stuart Hall and Paul du Gay. SAGE Publication, 199. pp. 1-17.

[12] Massey, Doreen. Space, Place and Gender. Polity, 1994.

[13] Mukherjee, Meenakshi. "A House for Mr. Biswas." Frontline: India's National Magazine vol.18, 2001, pp. 1-5.

[14] Naipaul, V. S. Half a Life. Picador, 2002. 